\title{
Chinese entrepreneurs and workers at the crossroad: the role of social networks in ethnic industrial clusters in Italy
}

\author{
Mario Biggeri \\ Economics and Management, University of Florence, Florence, Italy \\ Lisa Braito \\ Statistics, Computer Sciences, Applications “G. Parenti”, University of Florence, \\ Florence, Italy \\ Annalisa Caloffi \\ Economics and Management, University of Florence, Florence, Italy, and \\ Huanhuai Zhou \\ Zhijiang College, Zhejiang University of Technology, Shaoxing, China
}

\begin{abstract}
Purpose - This paper aims to analyse the evolution of Chinese industrial ethnic clusters in Italy, by focusing on the role of social networks and the processes behind the phenomenon of Chinese worker exploitation and entrepreneur "self-exploitation".

Design/methodology/approach - The case study is a sub-cluster of micro and small enterprises owned by Chinese entrepreneurs within the leather industrial district of Florence, Italy. This research adopts the following mixed methods: a small-scale survey to capture the characteristics of the sub-cluster and a social network analysis to describe cluster evolution, complemented by life-course interviews conducted with key informants and entrepreneurs.

Findings - Migrant social capital and social networks play a central role in the evolution of the case study subcluster. Social networks play a supportive role in migration, job creation, entrepreneurship formation and the creation of business opportunities. Simultaneously, they enhance the phenomenon of worker exploitation and entrepreneur self-exploitation. Furthermore, the more the business community grows, the more the economic performance of ethnic enterprises depends on agglomeration forces produced by the cluster.

Practical implications - The findings suggest a series of potential policies to upgrade the ethnic enterprises' capacities, to increase their formality and inclusion in the Italian social and economic systems and sub-cluster. Originality/value - To the authors' knowledge, this paper is the first attempt to examine the evolution of social networks in relation to the phenomenon of Chinese worker exploitation and entrepreneur selfexploitation in an ethnic industrial sub-cluster.
\end{abstract}

Keywords Industrial clusters, Social capital, Chinese entrepreneurs, Ethnic enterprises

Paper type Research paper

(C) Mario Biggeri, Lisa Braito, Annalisa Caloffi and Huanhuai Zhou. Published by Emerald Publishing Limited. This article is published under the Creative Commons Attribution (CC BY 4.0) license. Anyone may reproduce, distribute, translate and create derivative works of this article (for both commercial and non-commercial purposes), subject to full attribution to the original publication and authors. The full terms of this license may be seen at http://creativecommons.org/licences/by/4.0/legalcode

An ethical committee was established to verify the ethical aspects related to tools and research processes. The committee was comprised of an NGO member and two academics. The overall research study was coordinated by Mario Biggeri, while field research was coordinated and conducted by Huanhuai Zhou. The authors are grateful to the Wenzhounese community for their kindness.

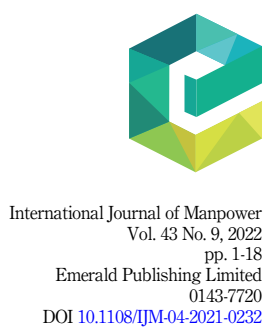


IJM

43,9

2

\section{Introduction}

In the literature on entrepreneurship and ethnic entrepreneurship, social networks both open opportunities allowing access to resources facilitating entrepreneurial activity (Yang et al., 2012; Portes and Martinez, 2020) and restrain entrepreneurs restricting access to and spill over of knowledge and technology and inducing labour exploitation (Rahman et al., 2018). In other words, "the community is simultaneously nurturing and confining" (Jones et al., 2014, p. 503). This is in line with the literature attention paid recently to the phenomenon of ethnic entrepreneurship in industrial district/cluster [1] (Canello, 2016; Dei Ottati, 2017; You and Zhou, 2019; Portes and Martinez, 2020).

This paper aims to analyse the evolution of Chinese migrant entrepreneurship in the context of industrial cluster in Italy, by focusing on the role of social networks and the phenomenon of exploitation and "self-exploitation" [2].

According to the ethnic entrepreneurship literature (Portes, 1995; Deakins et al., 2007; Wang and Altinay, 2012; Zolin et al., 2016), migrants form tight social networks with fellow nationals, which are grounded in an ethnic-based social capital composed of common language, culture, religion, conventions and customs, kinship relationships or personal knowledge, trust and common understanding. Social networks based on the sharing of the same social capital can help to identify business opportunities and to increase social reputation, which are both vehicles to access capital as well as cheap co-ethnic labour (Portes and Martinez, 2020).

Exploitative working conditions may emerge in these contexts (Rahman et al., 2018). The existing literature on clusters sometimes disregards that evolution and economic upgrading may not be translated into social upgrading (Gereffi and Lee, 2016), perpetuating vulnerability and generating adverse outcomes for workers' well-being (Caroleo et al., 2010). In the case of ethnic entrepreneurship, cheap co-ethnic labour force allows the firm to remain costcompetitive and flexible (Ceccagno et al., 2008). To rely on labour cost cuttings and abnormal working conditions (piecework, over-hours, contractual, contributory and wage irregularities) is seen by the first generation of migrants as "acceptable", as both are labour-intensive, but this is not appropriate from a labour legislation perspective. Indeed, according to Ceccagno et al. (2008), "over time, it becomes evident that the Chinese manufacturing enclave is also the result of a shared vision between employers and workers, a vision that implies exploitation and self-exploitation [ ... ] and is perceived as favourable for both" (p. 87).

According to the mixed embeddedness approach (Kloosterman, 2010), an individual agent, with his/her resources, competencies and social embeddedness, has to be complemented by wider meso/macro institutional contexts that define opportunity structures for the former.

The industrial districts and clusters can be considered a fertile meso-level environment for this type of ethnic firm and cluster (Barberis and Aureli, 2010; Kloosterman, 2010; Yang et al., 2012). One of the most interesting country-case studies of this phenomenon is Italy, where Chinese ethnic entrepreneurship intermingles with the presence of industrial districts and clusters (Dei Ottati, 2017) [3]. In this paper, we define these phenomena of ethnic enclave industrial clusters/sub-clusters as local system of production characterised by the emergence of ethnic enclave economies within already established industrial clusters (see also Barberis and Aureli, 2010).

Nevertheless, the above-mentioned literature overlooks micro-entrepreneurial ethnic clusters and the processes behind the formation of enclave networks in the diaspora (Epstein and Heizler, 2016), as well as the phenomenon of migrant worker exploitation and micro-entrepreneur selfexploitation (Jones et al., 2006; Ojo et al., 2013). One of the main reasons for this, as underlined by Canello (2016), is the difficulty in collecting information and micro-data on these issues.

This study explores, as a case study, the evolution of the Chinese immigrant socioeconomic enclave that grew in the leather industrial district located in Florence, by focusing on the role of social networks and the cluster's external economies. 
Regarding the evolutionary path of the ethnic sub-cluster, and adopting a long-term horizon perspective, our hypothesis is that without any upgrading strategy that encompasses both economic and social upgrading, the only possible "breakingout" strategy (Arrighetti et al., 2014) is to exit from the sub-cluster.

Given the lack of previous research and the complexities of collecting data in this community, a mixed-method approach has been adopted. To reconstruct the history of the sub-cluster, we conducted observational field research, including in-depth interviews with key stakeholders and life-course interviews with entrepreneurs. Then, we ran a survey by administering questionnaires to a random sample of entrepreneurs (212) to assess working conditions, and a questionnaire to a nested sample of 24 entrepreneurs, to analyse the social relations in which they were engaged, which we then analysed through social network analysis (SNA) techniques and developed some multiplex networks.

This article is structured as follows. Section 2 introduces the main streams of literature that constitute the foundation of the research study. Section 3 presents the methodology, and Section 4, an initial description of the observed sub-cluster is provided. In Section 5, the results of the SNA, together with those of the life-course interviews, are discussed. In Section 6 , building on the results of the empirical analysis, a lifecycle model of the ethnic sub-clusters is sketched. Section 7 concludes.

\section{Chinese ethnic enterprises in industrial districts in Italy}

The global position acquired by China in several traditional "made in Italy" manufacturing industries has had consequences for industrial districts in Italy, in many cases accelerating their transformation or even their decline (Bellandi and Caloffi, 2008). However, Chinese entrepreneurs have also been an important element of change from within (Ceccagno, 2003; Barberis and Aureli, 2010; Canello, 2016; Dei Ottati, 2017). In 2007, 64\% of the total number of micro and small firms owned by Chinese entrepreneurs were settled in (pre-existing) industrial districts in Italy. Moreover, $31 \%$ of the total number of enterprises operating in Italy in the traditional "made in Italy" sectors were Chinese-owned (Lombardi et al., 2015). According to some scholars, these two industrial communities share a common model of "ethno-industrialisation", which is based on small firms run by entrepreneurs collaborating and competing along the same production chain and sharing the same social capital (Barberis and Aureli, 2010). Indeed, some areas of China, such as Wenzhou, in Zhejiang Province, are characterised by family-owned micro, small and medium-sized enterprise (MSME) clusters, which bear some similarities with the clusters in Italy (Walcott, 2007).

Literature on industrial districts in Italy has shown that the competitiveness of clusters of specialised small firms is based on the possibility of realising a number of external economies, i.e. benefits accruing to firms as a result of being embedded in the district (Becattini, 1989). District literature has shown that social capital affects the processes behind the generation and subsequent development of firms by providing local entrepreneurs with low-cost access to a number of suitable human, cognitive and financial resources, thus creating effective connections with the international market. Similarly, while local demand plays an important role in the birth and early development of the cluster - allowing it to realise scale and scope economies - in the later stages of development, growth is also driven by success in the world markets.

Chinese social capital seems to provide a solid foundation for the development of stable social networks, because it includes implicit norms of reciprocity (guanxi, which implies an obligation to return a favour) and trust (Park and Luo, 2001). These norms are reproduced over time, also in the context of migrant communities, because entrepreneurs, particularly those coming from the Wenzhou Province, exhibit a relevant social closure and in-group selfreference (Pieke and Mallee, 1999). Particularly in a cluster context, the external economies 
IJM

43,9

4

that support the development of agglomerated firms, which also include a "social network effect" (Gordon and McCann, 2000), can provide stronger support than ethnic networks. However, few studies offer in-depth exploration of the role of social networks in the subsequent development of ethnic clusters and enterprises.

To fill this gap in the literature, we try to explore the relative strength and weakness of social networks and cluster agglomeration forces in supporting the creation and the development of ethnic enterprises and clusters. Since migrant entrepreneurs and ethnic MSMEs, constituting ethnic enclave industrial sub-clusters, are embedded in a multilevel opportunity structure that shapes the opportunities and threats encountered by both individual firms and the cluster itself, we customised the mixed embeddedness framework (Kloosterman, 2010). To achieve a dynamic interpretation (You and Zhou, 2019) of the evolution of the ethnic enterprises in the case study, we consider three levels of analysis (Figure 1): the micro level of both Chinese immigrants as workers and entrepreneurs and their micro-enterprises endowed (or not) with some resources and relations; the meso level of the ethnic enclave industrial sub-cluster; and the macro level of the regional and national socioeconomic setting and the global dynamics affecting both the workers and the enterprises, although this will remain in the background of our analysis.

The social networks available to the workers and the micro-enterprises cross all spheres of influence. Indeed, exploitative working conditions are mainly to be found at the micro level but are perpetuated also in the meso and macro levels if we consider the role of the international diaspora and the business and social relations with the home country in shaping the opportunity structure of the firms and entrepreneur. Ethnic resources are thus not only to be found at the micro and meso level (i.e. sub-cluster level) but also in the wider globalised socioeconomic setting, which enables opportunities on one side and creates fierce competition on the other.

Figure 1.

Diagram of the conceptual framework

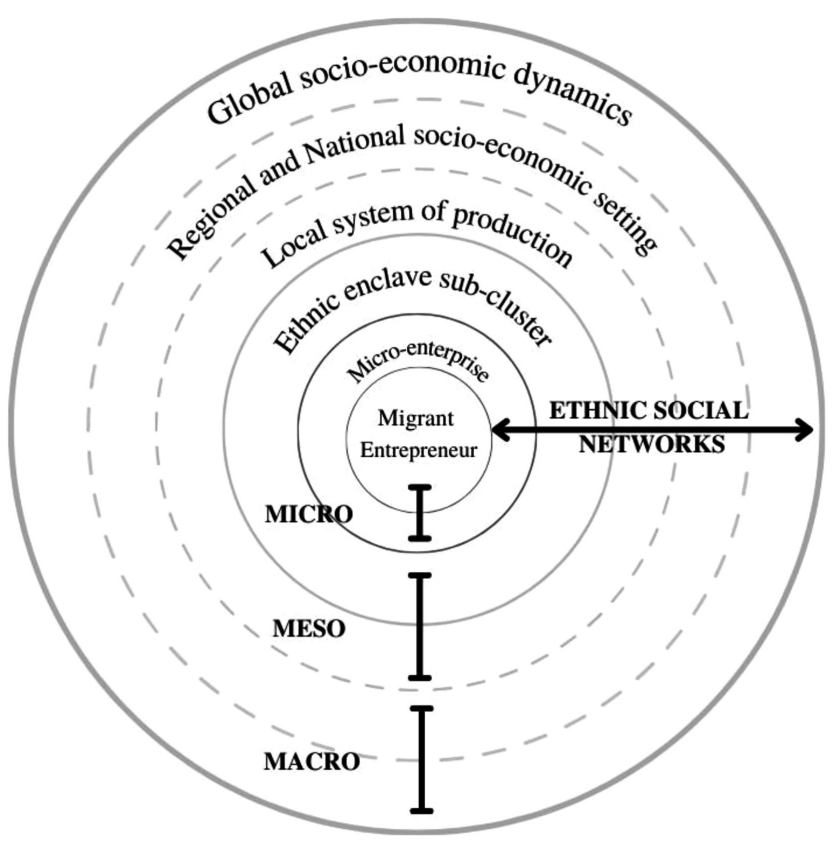

Source(s): Authors' elaboration on Kloosterman (2010) 
Considering our case study, the meso level comprises also the empty sector market left by native businesses that are unable to compete internationally and locally with ethnic businesses, which have lower production costs (even if at the expense of the quality of labour, exploitation and compliance with the rules). Moreover, meso-level dynamics have spill-over effects on the working conditions in the ethnic micro-enterprises since their main competitive advantages are low labour costs and high productivity (considering the high labour intensity of the production of leather bags), which allow them to survive and exist in the local system of production.

\section{Methodology}

Considering scarce general information and the general difficulties entailed in collecting microdata in ethnic-enclave industrial sub-cluster (Mehrotra and Biggeri, 2010; Canello, 2016), an integrated mixed-method approach has been adopted.

First, extensive observational research was carried out. For one year, a Wenzhounese researcher lived embedded within the Chinese community of the Osmannoro district of Florence, so as to familiarise herself with its members and community. Then, interviews were carried out with key stakeholders (Italian and Chinese entrepreneurs, Chinese workers, Chinese wholesale retailers and members of local business associations and government). Moreover, 12 life-course interviews with Wenzhounese entrepreneurs were conducted, focusing on the turning points of their personal and business experiences in Italy. These Chinese migrants' experiences were analysed at three turning points: (1) the point at which they arrived in Italy and commenced work $(t 1)$; $(2)$ the point at which they became entrepreneurs ( $t 2)$; and (3) the point at which their enterprises began to grow, in the context of an expanding sub-cluster ( $t 3)$.

A general survey was conducted with the aim to interview entrepreneurs, who were randomly selected using two-stage sampling (71 entrepreneurs were interviewed with a $2.25 \%$ error), allow to gather information on the single enterprise and the working conditions.

To analyse the ego network, a second small-scale survey was carried out by delivering questionnaires to 24 entrepreneurs, who were randomly selected as a nested sample from the 71 entrepreneurs previously interviewed. We asked entrepreneurs to indicate the names of agents (following a name generator strategy) who had provided them with different types of relations: personal and/or business. The former provides kin support to migrate to Italy and to find a home and a job. The latter offers technical advice, business advice, financial support, trade relationships or contacts with customers, providers and other partners in production. Moreover, information about the attributes of each agent, as well as the intensity and duration of the relationship, was collected.

These data were analysed by adopting an ego-network perspective and a multiplex networks procedure (Crossley et al., 2015). The former implies starting from the observation of the individual (the ego) and then trying to reconstruct the network of relationships with alters at each of the three turning points $(t 1, t 2$ and $t 3)$. Information on the relationships among alters, when available, was also used, providing evidence of the presence of a web of linkages connecting many (or even all) Chinese entrepreneurs located in the sub-cluster.

Being well aware that we cannot infer the entire network from a random sample of egonetworks, this perspective allows us to identify some nodes that play an important intermediary role between the different ego-networks, as will be discussed Section 5 .

Given that we observe different types of relationships (e.g. parental, social or business), we get multiplex networks, which are networks that describe multiple relations among the same set of actors. These are based on several different squared matrices (ego*ego), each of which stores data related to a particular type of relation. The connection between these matrices is 
IJM

43,9

given by the measurement of different relations on the same sample (Lee et al., 2014). By calculating a simple Pearson correlation index between matrices, we can measure the degree of association between different types of relations characterising the same agent. To test the association between networks, we perform the quadratic assignment procedure (QAP) test that is implemented in the UCINET software. The QAP algorithm proceeds in two steps: first, it calculates the Pearson's correlation coefficient $r$ among corresponding cells of the matrices; second, it randomly permutes rows and columns of one matrix and recalculates the correlation. The second step is carried out 5,000 times, to compute the proportion of times that a random measure is larger than, or equal to, the observed measure calculated in Step 1. A $\mathrm{QAP}<0.05$ tells us that the relationship between the matrices is strong. The $r$ is calculated both on the directed and on the symmetrised matrices (Simpson, 2001).

Finally, the data gathered from the life-course interviews help us to interpret the results of these correlations and of the whole SNA, in general.

\section{The ethnic sub-cluster in Florence's leather industrial districts}

The production of leather goods in Florence, which can claim lineage to ancient traditions, is nowadays organised in an industrial district characterised by the presence of large fashion companies (including multinational companies) owned by globally recognised luxury fashion brands (e.g. Gucci, Ferragamo and Céline), and a large number of MSMEs acting as their subcontractors, among which a large community of Chinese immigrants originating from Wenzhou acts as a quasi-enclave economy (Randelli and Lombardi, 2014).

According to official data from the Chamber of Commerce of Florence, in 2012, in the whole province of Florence (a much larger area than the cluster), a total of 2,054 nonindividual enterprises were involved in leather goods production, of which 1,003 (almost $50 \%$ ) were Chinese. In 2019, the number of Chinese enterprises grew to 1,736 (of a total 3,612 non-individual enterprises), representing an increase of $73.1 \%$. In 2012 , the number of registered individual enterprises within the whole province amounted to 1,119 (of a total3,508 workers); of these, 949 were Chinese-owned (84.8\%), representing an increase of $34.4 \%$, relative to 2011. In 2019, the number of registered individual Chinese entrepreneurs within the leather goods production industry was 1,541 of a total $1,774(86.9 \%)$, representing an increase of $62.4 \%$ since 2012 (employing 6,720 workers in total).

According to key informants and the limited literature available (Tassinari, 1994), in the 1970s, fewer than 200 migrants from Wenzhou lived in the province of Florence (outside the historical city centre), and most were involved in bag retail. In subsequent years, some Chinese entrepreneurs entered into bag production, imitating the characteristics of the Italian products they were accustomed to selling. For instance, while in 1983, there were only six Wenzhounese family-owned firms, that number rose to more than 400 in the early 1990s, after they found a suitable area for production in Osmannoro, an industrial and commercial area bordering the municipalities of Florence and Sesto Fiorentino, where several vacant warehouses became available after Italian entrepreneurs either closed or moved to less congested areas. Thus, Osmannoro became the heart of the quasi-enclave leather-producing ethnic-Chinese cluster.

According to our field research, the Chinese ethnic sub-cluster currently includes around 1,000 family-owned Chinese micro-firms specialised in the production of low-quality, low-cost bags. On average, these enterprises employ 3.08 workers, including the entrepreneur, while only less than $5 \%$ employ more than five employees. Each firm occupies a small area within big warehouses, ranging from 30 to $100 \mathrm{sq} \mathrm{m}$ in size. This ethnic sub-cluster is geographically located near the leather industrial district, but the two interact in only a small number of cases: e.g. when Chinese entrepreneurs decide to delink from the ethnic sub-cluster and start producing as sub-contractors for Italian companies. 
From the data collected, one of the most relevant characteristics of the ethnic sub-cluster, in terms of social capital and networks, is the thickness and homogeneity of the network. Indeed, almost all Chinese-born entrepreneurs (around 99\%) come from Wenzhou City, in China's Zhejiang Province. Of these, 95\% come from Rui'an City and Wencheng County, two districts that fall under the administration of Wenzhou City. Despite its small size, the business network comprises wide-ranging connections not only within China but also all over Europe, thanks to the Chinese diaspora and Wenzhounese entrepreneurial networks. Over $94 \%$ of these MSMEs export abroad (throughout Europe, in particular, to Germany and France). Leather bags are mainly sold to European retailers (often managers of stalls in street markets) or wholesalers (not necessarily Chinese), who often personally visit the sub-cluster. The extent of their non-ethnic business networks contributes to our defining this agglomeration of ethnic firms as a quasi-enclave economy. Nevertheless, they are embedded in a thick local and regional network, since more than $50 \%$ receive recurrent orders from within both Florence and the broader Tuscany region.

According to the results obtained via our observational study and key informant interviews, competition among cluster firms is high. Entrepreneurs are highly competitive of each other's production, as the firms produce similar (in terms of design and raw material acquired from the same providers) leather products of low- or medium-low quality. Therefore, competition is based on low prices and cost compression, and cooperation exists only in terms of financial assistance. General conditions - in terms of workplace safety, environmental management, employment contracts, taxation and hygiene - are similar to shoemaking clusters in Wenzhou and can be considered even worse than those described in the nearby clothing/textile ethnic clusters in Prato (Biggeri et al., 2015). Notably, informal modes of operation, such as verbal labour contracts, are common.

According to the data collected via our survey, despite adaptive preferences, workers negatively evaluated their long working hours and the intensity of their work and the workplace conditions. Almost $40 \%$ of workers evaluated the long working hours as bad, while $82 \%$ evaluate the job intensity as not good.

According to the general survey, the working conditions are homogeneous - across firms, time and worker status, i.e. employers and employees - and very debilitating. The major proxies we used to analyse the working conditions (and, thus, exploitation) are the number of working hours and of working days. We were able to assess them on all the households (not only the entrepreneurs) surrounding the 71 interviewed enterprises. Excluding children, elders and relatives not working for the enterprises we were able to gather information about 216 workers. As showed by Table 1, the average working schedule amounts to $86 \mathrm{~h}$ per week, more than double the Italian standard of $40 \mathrm{~h}$ per week. This increases even more in the case of non-relatives and distant relatives' employees. Although, on average, the hourly wage received by a Wenzhounese worker is much lower (around $€ 4$ to $€ 4.5$ per hour) than that earned by the average Italian worker (the Italian minimum hourly wage is $€ 7.5$ ), the average monthly salary of each ends up being similar due to the excessive working hours of the former. These harsh working conditions (i.e. the number of working hours and tiring nature of the work) constitute a relevant indicator of labour exploitation and self-exploitation and, simultaneously, unfair competition for legally operating firms, considering their low contribution to the fiscal system while benefiting from access to basic social services such as free education and healthcare.

\section{Understanding the structure of the Chinese social networks}

In this section, we present the main results of the SNA that map the evolution over time (at $t 1$, $t 2$ and $t 3$ ) of the different types of relationships in which the egos are involved, triangulating them with their life-course interviews. Three emblematic and successful Chinese 


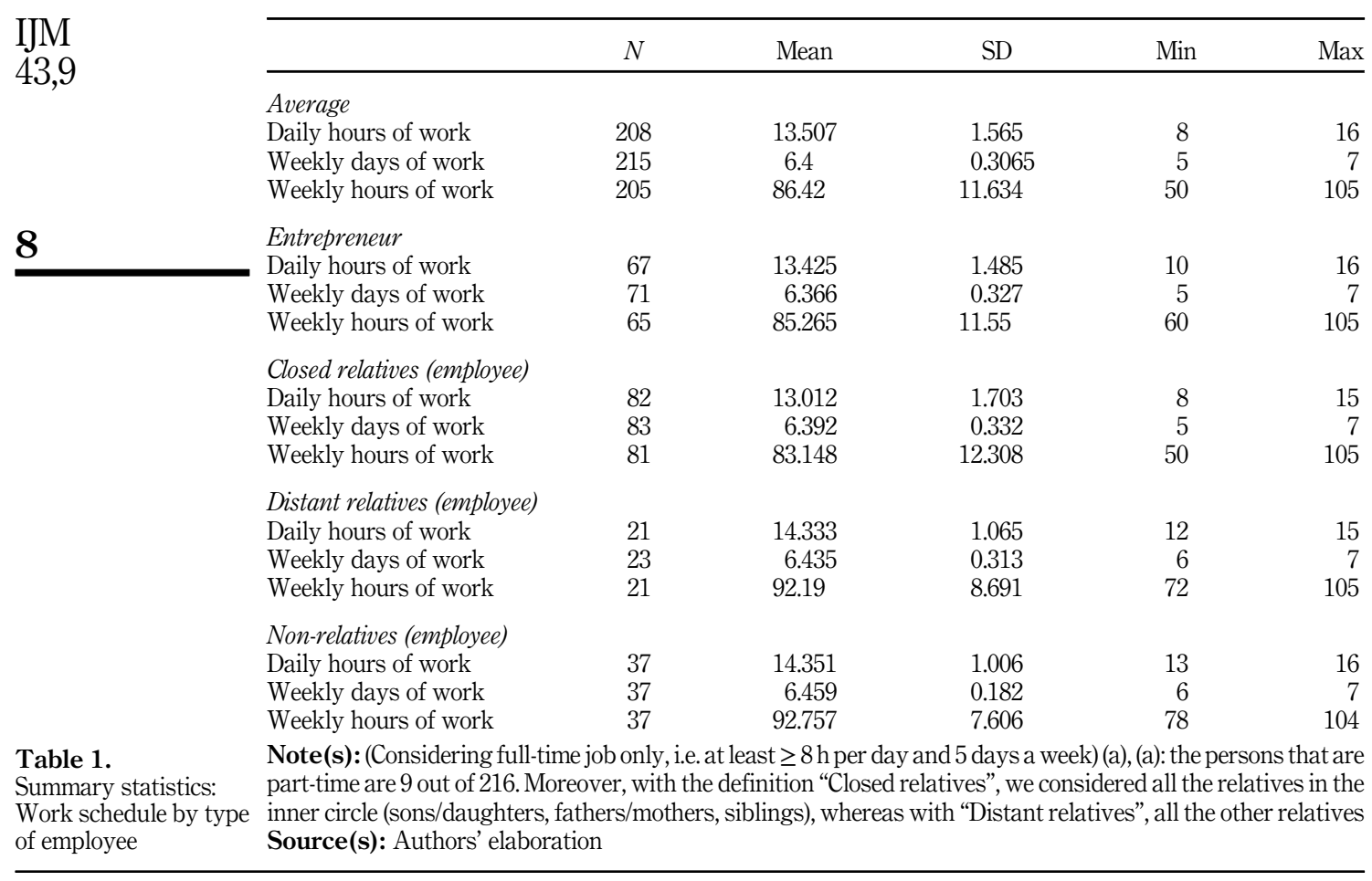

entrepreneurs, renamed as $\mathrm{Mr} \mathrm{P}, \mathrm{Mr} \mathrm{Q}$ and $\mathrm{Mr} \mathrm{O}$, will help us to navigate the social networks and their evolution over time.

\subsection{Ego arrives in Italy ( $t 1)$}

Almost all the immigrants from Wenzhou arrived in Italy because of the financial support of their Wenzhounese friends or families, either on work or family visas. Some arrived without a visa, remaining as illegal immigrants until, at the beginning of the 1990s, a national law allowed for their regularisation. Most of them could not speak Italian. Moreover, most of the people we interviewed $(61 \%)$ had a low level of education corresponding to that of junior high school, while about $30 \%$ had attended primary school only. Most were unemployed while in Wenzhou, and at the time of their arrival, they had no specific skills. This was especially true for the women, the majority of whom were housewives in China.

Let us analyse this picture in terms of the 24 ego-networks. Figure 2 depicts several disconnected ego-networks centred on focal agents (represented by white circles characterised by thicker black borders). At $t 1$, the focal agents under observation were operating as individuals (not yet firms) with numerous personal relations or business agreements with various agents (relatives or friends). These relations are not clusterspecific, since relatives and friends are often situated outside the cluster, in China or in different cities in Italy or Europe. Relatives and friends become "supporters" when they provide financial support to the ego to migrate to Italy, and the relationship between the ego and the supporter is based on a simple verbal agreement, made before the migrant travels to Italy. This agreement creates a debt (related to travel and accommodation costs) that the 


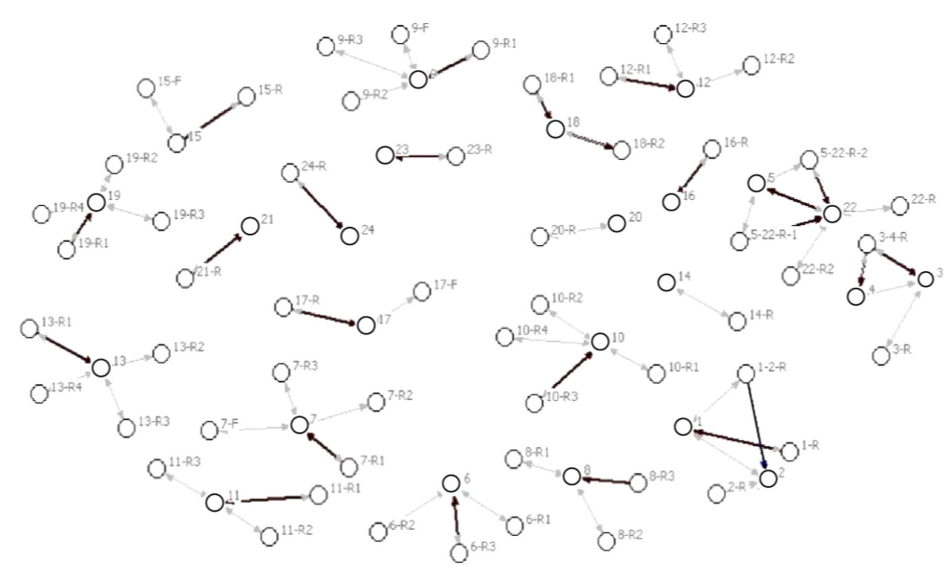

Social
networks in
ethnic
enterprises

9

Note(s): Focal agents are represented by white circles characterized by thicker black borders. Standalone white circles are the focal agents' relatives and friends. Directed edges represent personal relations (highlighted in grey); black lines represent personal relations intertwined with business relations

Source(s): Authors' elaboration

Figure 2.

The network at $t 1$

migrant worker must pay back by working for the supporter. On average, migrants have to work for approximately four years to fully repay their debt.

Usually, during the initial years after arrival in Italy, the ego must acquire new skills. If the ego is hired by a company belonging to the leather cluster, the learning process is eased by the low-tech and low-skill stages of bag production. After a period of work, the ego is not only able to manufacture bags but is also able to manage a small bag-making business.

The situation displayed in Figure 2 is highly fragmented since most of the 24 egonetworks we observed (currently settled in the ethnic leather sub-cluster) at $t 1$ were disconnected from the others. Only some of the focal agents were connected through common friends or relatives. Business relationships always intermingle with personal links (with only one exception, i.e. the link between agent 1-2-R and focal agent 2) and often stem from preexisting personal relations, as confirmed by key informants' interviews.

Table 2 summarises information about the networks displayed in Figure 2, as well as information regarding the networks at $t 2$ and $t 3$ (Figures 2 and 3 ). The ego-networks that we observe at $t 1$ are quite small (2.63 and 1.04 links on average), and there is a high statistically significant correlation between business and personal relationships.

Following the life-course interviews for egos in $t 1$, we found interesting evidence.

In 1983, Mr P had a stable job as a salesman in a collective township and village enterprise in Wenzhou, but his salary was extremely low (approximately $¥ 33$ per month). At that time, the salary in Europe for the same job was much higher (approximately $¥ 7,000$ in The Netherlands and between $¥ 4,000$ and $¥ 5,000$ in Italy). Mr P decided to move to Europe to pursue his aspiration to become wealthy. In 1987, he received some money from his sister, who was living in The Netherlands, so that he could join her. In 1990, after working for several years as a dishwasher in a Chinese restaurant owned by his sister, he came to know of an opportunity from relatives settled in Italy: the Italian government was giving a resident permit to illegal migrants in Italy. Mr P decided to move to Italy, having ascertained that his relatives would provide him a job. As soon as he arrived, he started working in a small 


\begin{tabular}{|c|c|c|c|c|}
\hline \multirow[t]{5}{*}{$\begin{array}{l}1 \mathrm{MM} \\
43,9\end{array}$} & Number of focal agents & $\begin{array}{l}t 1 \\
24\end{array}$ & $\begin{array}{l}t 2 \\
24\end{array}$ & $\begin{array}{l}t 3 \\
24\end{array}$ \\
\hline & Average size of personal ego-network & 2.63 & 2.63 & 6.92 \\
\hline & Number of personal relations & 63 & 63 & 166 \\
\hline & Localised in the ethnic cluster & - & - & $35.5 \%$ \\
\hline & Localised in Florence metropolitan area & - & - & $6.0 \%$ \\
\hline \multirow{10}{*}{10} & Localised in Tuscany and other areas of Italy & - & - & $35.5 \%$ \\
\hline & Localised in other European areas & - & - & $22.9 \%$ \\
\hline & Average size of business ego-network & 1.04 & 1.96 & 4.42 \\
\hline & Number of business relations & 25 & 47 & 106 \\
\hline & Localised in the ethnic cluster & - & - & $29.2 \%$ \\
\hline & Localised in Florence metropolitan area & - & - & $1.9 \%$ \\
\hline & Localised in Tuscany and other areas of Italy & - & - & $40.6 \%$ \\
\hline & Localised in other European areas & - & - & $28.3 \%$ \\
\hline & Pearson correlation between business and personal relations (directed matrices) & $0.430^{*}$ & $0.550 *$ & 0.015 \\
\hline & Pearson correlation between business and personal relations (symmetrised & $0.607^{*}$ & $0.768^{*}$ & 0.021 \\
\hline
\end{tabular}

Table 2.

Characteristics of the networks' evolution matrices)

Note(s): The average size of ego-networks refers to the (average) number of nodes that are one-step-out neighbours of an ego. The star indicates that the QAP test is $<0.05$ (correlation is statistically significant) Source(s): Authors' elaboration

enterprise owned by a relative, producing leather bags in San Donnino (a small village in Campi Bisenzio municipality).

Mr Q had a similar story to tell. He attended school in China and, during the 1980s, started a business in Wenzhou. However, the venture failed, and so he lost the money he had borrowed from relatives and friends. He subsequently found a new job, but the salary was incredibly low (around $¥ 300$ per month). Given both his need to repay his debts and his aspiration to become wealthier, he decided to move to Europe. In 1994, he arrived in France as an illegal immigrant and started working in a friend's restaurant as a dishwasher. The job was demanding, and his aspirations were frustrated, so after repaying the debt to his friend, he decided to move to Florence, where his sister was living. In 1997, he started to work in his sister's enterprise producing bags.

Compared with $\mathrm{Mr} \mathrm{P}$ and $\mathrm{Mr} \mathrm{Q}$, in 1995 , $\mathrm{Mr} \mathrm{O}$ was earning a good salary $(¥ 2,000)$, being a specialised worker in a water supply company in Wenzhou. However, he was dissatisfied with his life and wanted to be wealthier, so he started saving money to travel abroad. When his father's friend - who had migrated to Italy and opened a small business producing leather bags - told him about the high income he was earning there, $\mathrm{Mr} \mathrm{O}$ decided to follow his example, as doing so required neither specialised skills nor much money. Given that he had insufficient savings, he repeatedly tried to enter Italy illegally, finally succeeding in 1996. Once there, he settled in his uncle's house and started to work in a small firm that produced bags, which was owned by one of his uncle's friends (a Wenzhounese entrepreneur).

\subsection{Ego creates its own firm (t2)}

At this turning point, having repaid their initial debt to supporters and having learnt how to manufacture bags, individuals create their own firms. As shown in Figure 3 , at $t 2$, individuals are still very much embedded in a network of personal relations, which intertwines with that of business relations but in an almost doubled business network than in the previous period (these pass from 1.04 to 1.96 links on average). To start their own ventures and find their own 
clients, new entrepreneurs require material and immaterial resources. As it is more difficult for the aspiring entrepreneurs to obtain funds through formal mechanisms, such as bank loans, informal interpersonal networking constitutes the main financing channel. Moreover, the entrepreneurs seek the help of friends and relatives, who are in the same line of business, to secure orders. The opportunity structure is framed by the presence of a cluster, which makes the small production viable and the status of entrepreneur desirable, at least for the first generation of immigrants (Ceccagno, 2003).

The situation is represented in Figure 3. Our focal agents are embedded within a larger network than in the previous period (here we considered resources to be financial capital, technical advice and demand). While personal relationships are highlighted in grey, business relationships are highlighted in black. As we can clearly see from Figure 3, almost all the personal relationships coincide with the business relationships. Indeed, the correlation between business and personal networks is high and statistically significant (Table 2).

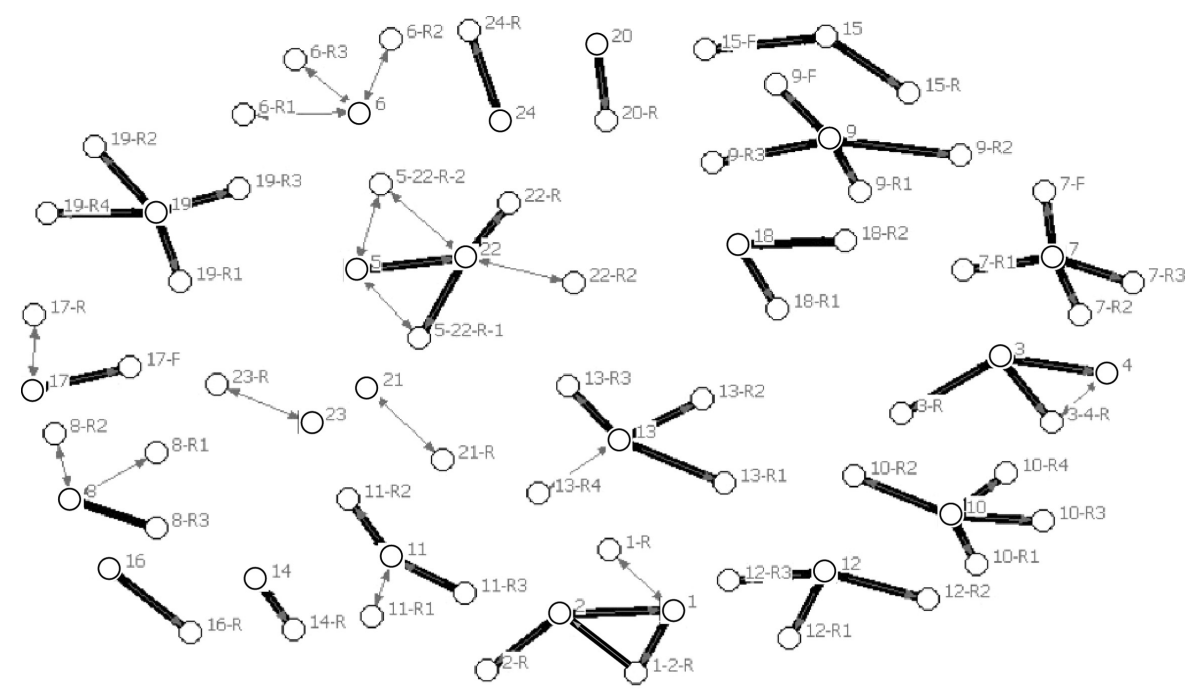

Note(s): Focal agents are represented by white circles characterised by thicker black borders. Standalone white circles are the focal agents' relatives and friends. Directed edges represent personal relations (highlighted in grey); business start-up relations (highlighted using black lines) represent personal relations that are intertwined with business relations. Lines have different thickness on the basis of the intensity of the relations

Source(s): Authors' elaboration

Figure 3. The network at $t 2$

According to their life-course interviews, $\mathrm{Mr} \mathrm{P}, \mathrm{Mr} \mathrm{Q}$ and $\mathrm{Mr} \mathrm{O}$ started to use the ethnic social networks to support their business.

In 1991, Mr P started his own business in San Donnino, having learnt how to make bags by working for one year in a workshop owned by a relative. To create the firm, he borrowed money from his sister and friends. After a few years, he was able to repay his (second) debt from the profit generated by his business. He originally employed two to three workers; however, in 1995, after moving his business to the nearby Osmannoro district, he was able to hire an additional three employees. He has also assisted friends from Wenzhou to migrate to 
IJM

43,9

12

Italy and, in time, to set up their own firms, thus becoming a supporter himself and "breeding" other Chinese entrepreneurs.

Mr Q opened his bag-making company in 2000, after working in his sister's enterprise for three years to learn the job and having repaid his debt to his supporter. To open his own business, he borrowed money from his sister $(€ 3,000)$, in addition to friends (not more than $€ 1,000$ each), and received money as a wedding gift, collecting a total of $€ 10,000$. At first, business was difficult due to lack of clients, and sometimes he did not make enough money to buy leather. He resorted to borrowing small amounts of money from his sister whenever necessary. However, after a short time, his business began to operate relatively well, partly due to one of his friends being a wholesaler and thus placing many orders. Mr Q subsequently expanded his firm, gradually increasing the number of hired employees from one to six (in 2006).

$\mathrm{Mr} \mathrm{O}$ opened his firm in 2002, after working for six years to repay his debts. His boss had decided to move to another city, and $\mathrm{Mr} O$ purchased the company for a relatively low price. To start his own business, Mr O borrowed money from his sister-in-law, who was living in Italy, and by the following year had already earned enough money to repay his debt (approximately $€ 60,000$ ).

By the end of $t 2$, all three entrepreneurs had begun planning or implementing new business strategies.

\subsection{Ego's business develops ( $t 3$ )}

During the time period represented by $t 3$, the ego's company develops, in the context of an expanding sub-cluster. The network of personal relations remains important (increasing to 6.92 links on average), but now the ego's firm is benefiting, especially from some clusterspecific external economies. As shown in Figure 4, focal firms increase the number of egobusiness network relations with clients and providers (on average 4.92 links), but these

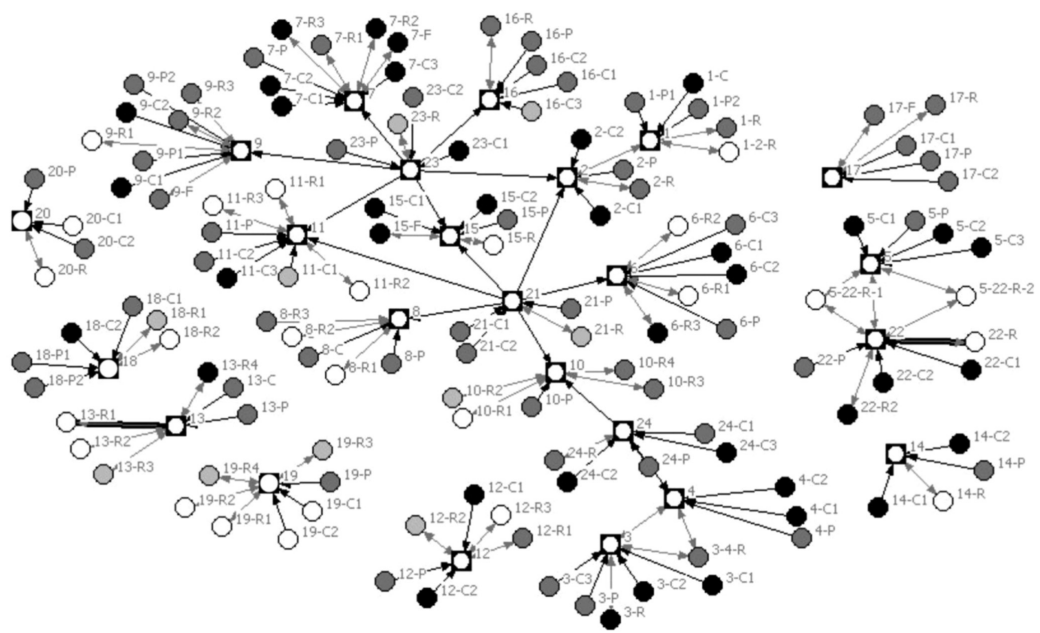

Note(s): Focal agents are represented by white circles within black boxes. Circles represent all other agents (clients, providers, friends, relatives, etc.). Nodes are marked as different colours based ontheir localisation:white nodes are localised within the cluster; light grey nodes are localised in the metropolitan area surrounding the cluster; dark grey nodes are localised in other areas of Tuscany and Italy; and black nodes are localised in other European cities. Directed edges represent the following:

Figure 4 .

The network at $t 3$ personal relations (highlighted in grey) and business relations (highlighted with a thin black arrow). Thick black lines represent personal relations that are intertwined with business relations

Source(s): Authors' elaboration 
relations do not necessarily intertwine with personal ones. The correlation coefficients for $t 3$ are low and, therefore, not statistically significant (Table 2).

This "emancipation" becomes possible because the sub-cluster has reached a critical mass and attracts external agents. Resources that are needed to expand the business, such as reputation or the opportunity to easily find business partners, are provided at low cost to subcluster participants as a result of agglomeration economies. For instance, suppliers of raw materials start to visit the sub-cluster to find new customers; therefore, egos no longer need to bear the relevant searching costs. In addition, companies benefit from the relevant savings in marketing costs, since, as the reputation of the sub-cluster increases, buyers from different Italian and European cities start to flow into this area to acquire their products. At this turning point $(t 3)$, business projects are also realised in collaboration with people from outside the ego's circle of friends and relatives (e.g. they enter the supply channel of the Italian leather cluster or of European companies).

Clearly, social networks remain important. For example, when the police order the seizure of a factory (e.g. for hygiene or safety issues or for serious irregularities related to employees), entrepreneurs can continue production in the factories of family or friends.

The $t 3$ turning point is confirmed by data obtained via the life-course interviews. Through the daily operations of his bag-making firm, $\mathrm{Mr} \mathrm{P}$ came into frequent contact with the providers of raw materials. He also came to know many Italian retailers and wholesalers from the nearby cluster of Santa Croce sull'Arno, who often visited the sub-cluster. Mr P identified a potential market opportunity for a company that could trade in both Chinese and Italian raw materials, so, in 1997, he became a wholesaler. While true leather is produced in Santa Croce sull'Arno, the artificial leather sold by his company was imported from the Chinese provinces of Jiangsu, Zhejiang and Fujian. Notably, Mr P had an agreement with several companies in Santa Croce, as he was their dealer within the Chinese cluster.

To take advantage of the business contacts he had acquired over the years (i.e. those of customers and other manufacturers), Mr Q opened a wholesale firm in 2011. He knew that external buyers flocking to the Chinese sub-cluster needed a contact point, and so he created one. The sub-cluster is now renowned, and his customers come from all over Europe. After some time, he expanded his business by offering a wider range of leather products that are produced not only in the Florentine sub-cluster, but also in other parts of Italy, such as Naples, as well as in China, particularly in Haining (in Zhejiang Province), which is famous for its leather products. Mr Q also sold bag accessories produced in India and China, thus becoming an important supplier of leather products and leather-related accessories.

$\mathrm{Mr} \mathrm{O}$ is a producer of bags, and although his firm is relatively small, his customers come from all over Europe, including Russia. He started to export abroad because the sub-cluster is often visited by foreign buyers, both Chinese and non-Chinese.

In summary, at the $t 3$ turning point, the Chinese-owned firms benefited from several external economies (e.g. marketing economies) that were realised thanks to the development of the sub-cluster. The growth of the sub-cluster boosts the growth of its individual firms, helping them to advance far beyond the boundaries of ethnic-based local networks.

\section{Understanding the lifecycle of the ethnic sub-clusters}

By drawing on the results of our research and our conceptual framework, we can chart an evolutionary path of the support provided by ethnic-based social networks towards the development of Chinese sub-clusters. Figure 5 depicts the lifecycle of the case study subcluster and its evolution.

In a first stage, running between $t 1$ and $t 2$, the importance of ethnic social networks increases exponentially both for individuals and for the whole sub-cluster. Regarding the latter, ethnic social capital drives the initial development of the sub-cluster by attracting 


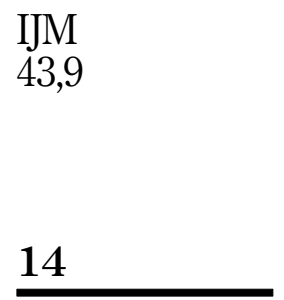

Figure 5.

The evolution of ethnic entrepreneurs in clusters
Contribution of the ethnic-based social network (ESNs) to the evolution of the ethnic cluster

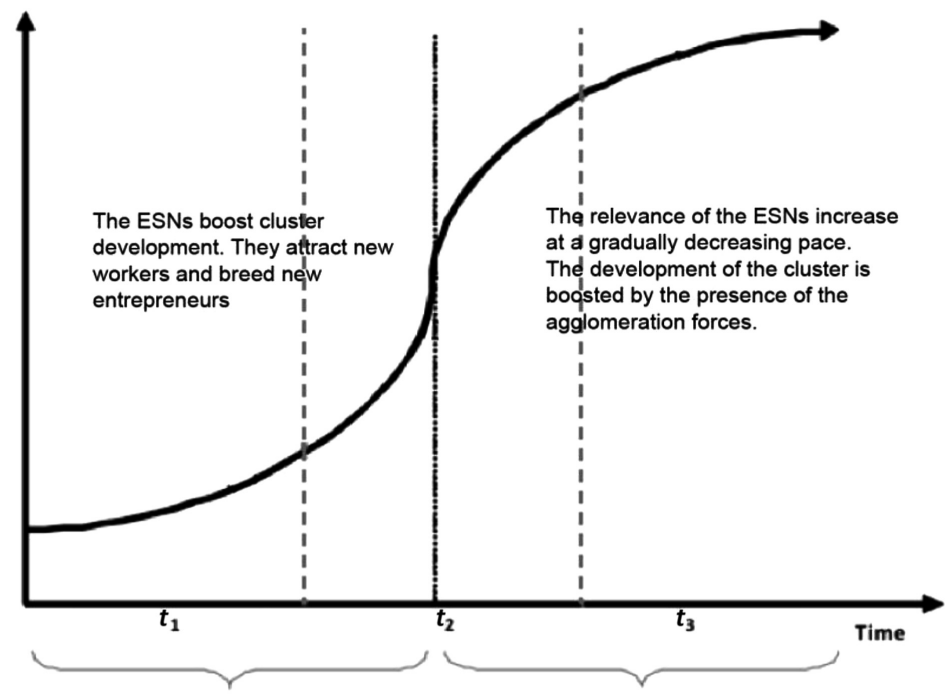

Source(s): Authors' elaboration

new migrants and enabling them to accumulate useful resources and competencies (e.g. reputation, skills and knowledge) so that they may upgrade to self-employment. At the beginning of $t 2$, the sub-cluster grows by spin-offs because migrant workers open their own firms. Simultaneously, the new entrepreneurs become supporters themselves, further fuelling the migration chain, firstly by increasing the co-ethnic workforce and then subsequently by boosting the enterprises' population within the sub-cluster. Both during $t 1$ and $t 2$, the networks not only are the vital force of the sub-cluster, but they also contribute to the growth in size of the sub-cluster keeping alive the mechanism of the vacancy chain (see also Deakins et al., 2007). In this stage, there are elements of the ethnic socio-economic system that facilitate the arrival of immigrants in Italy, which makes the creation and survival of the micro-enterprise possible. As we can see from the life-course interviews, Italian immigration legislation enacted at the beginning of the 1990s facilitated an influx of immigrants.

A second stage can be identified, in which the influence of social networks initially continues to increase, albeit at a slower pace, and then stabilises. While at an individual level, entrepreneurs start to envisage or implement new growth strategies by building on external mainstream linkages, new forces emerge at the cluster level that are related to external economies. Thanks to market forces, the ethnic sub-cluster is now able to attract new external customers. However, although the enterprises and the sub-cluster undertake a growth path, this growth is not necessarily combined with a social upgrade and a consequent improvement in employees' living and working conditions or with a transition from exploitation as employee to self-exploitation as employer (as seen in Section 4). Indeed, the sub-cluster can simultaneously continue to attract migrants, to generate new microentrepreneurs and to remain trapped in low-skilled and labour-intensive self-exploitative modes of production, although on a progressively larger scale.

The lifecycle we have drawn, although confirmed by the SNA, is not intended to be deterministic, i.e. it is one possible path of evolution. The cycle can stop and resume several times, and there may be loops and feedbacks that return the cluster to the starting point. 
The curve can continue in several ways. If the importance of ethnic networks gradually disappears, there will be a descending curve. This could happen, for instance, when the ethnic sub-cluster dissolves, either because of a crisis or because it melts with an Italian cluster. Moreover, some entrepreneurs decided to exit this ethnic sub-cluster, to avoid the lock-in effect (Jones et al., 2014).

The curve could also continue with a new growth phase. This could happen, for instance, if the sub-cluster becomes a bridge between Italy and China, by hosting several traders and manufacturers who rely not only on social networks developed within the ethnic subcluster, but also (and increasingly) on social networks centred on the motherland (You and Zhou, 2019).

\section{Conclusions}

The results of our research confirm that social networks within the Chinese community play a central role in the on-going processes of migration, job creation and entrepreneurship in clusters in Italy, as well as in searching for new trading opportunities all over Europe. However, though these networks are necessary (and probably sufficient) in the early stages of ethnic entrepreneurial activity, they are certainly not sufficient at later stages, when external and contextual cluster resources become central (in line with Zolin et al., 2016). This can happen if entrepreneurs are able to upgrade their skills and modify the firms' organisations structures so as to break out into mainstream markets (Arrighetti et al., 2014), i.e. in an upgraded level of the local system of production. Indeed, as the cluster system grows in size, the level of specialisation increases, and Chinese entrepreneurs benefit from external economies and cluster resources that are crucial to facilitate the upgrading (and in this case, the exit from the sub-cluster).

Overall, Chinese social networks generate significant benefits not only for current and future members of the community, but also for non-Chinese business partners. However, these networks also diffuse and perpetrate behaviours that are based on exploitation and self-exploitation, severe and irregular working conditions and social closure. We found that working conditions are homogenous across time and firms. Due to the low entry barriers, the continuous local and international demand for low prices products, the cheap labour supply and the consequent consistent and recurrent entry and exit dynamics in the market, the firms that exit the subclusters are substituted by other micro-firms perpetuating the same poor working conditions.

Therefore, as stated by the Decent Work Agenda of International Labour Organisation (ILO) and the 2030 Agenda for Sustainable Development Goals (e.g. SDG 8), these can constitute a limit to the future sustainable and inclusive development and the sub-cluster's social and economic development and integration into the broader Italian community: the Chinese community and entrepreneurs are at a crossroad.

Following the investigation of the nearby Prato Textile district (Biggeri et al., 2015), a twopronged strategy could be implemented to foster long-term sustainable and inclusive development. The first prong facilitates an exit from the vicious loop of exploitation and selfexploitation, which equates to an increase in the participation, consciousness and responsibility of the Chinese community and its entrepreneurs and civil society associations. The second prong facilitates the provision of policies aimed at upgrading the production capacity and security and sustainability of the ethnic sub-cluster, in terms of health, hygienic, environmental and social security and law compliance, thanks to the involvement of local associations of producers and consumers and the coordination of the metropolitan area of Florence and the wider Tuscany region.

\section{Notes}

1. We use the term district when referring explicitly to the literature on Marshallian industrial districts. 
IJM

43,9

2. The Chinese entrepreneurs of the Associazione della amicizia dei cinesi di Prato (Prato Chinese friends' Association) coined this term during events organised with the Tuscany region and Prato municipality in 2007 (Ceccagno et al., 2008).

3. The Italian micro-enterprises producing medium- or low-quality products have shrunk as a result of a mix of factors, including increasing global competition from China (Barberis and Aureli, 2010).

\section{References}

Arrighetti, A., Bolzani, D. and Lasagni, A. (2014), "Beyond the enclave? Break-outs into mainstream markets and multicultural hybridism in ethnic firms", Entrepreneurship and Regional Development, Vol. 26 Nos 9-10, pp. 753-777.

Barberis, E. and Aureli, S. (2010), The Role of Chinese SMEs in Italian Industrial Districts, Quaderni di Economia Aziendale no. 14, Urbino, Università degli Studi di Urbino "Carlo Bo", pp. 1-39.

Becattini, G. (1989), "Sectors and/or districts: some remarks on the conceptual foundations of industrial economics", in Goodman, E., Bamford, J. and Saynor, P. (Eds), Small Firms and Industrial Districts in Italy, Routledge, London, pp. 123-135.

Bellandi, M. and Caloffi, A. (2008), "District internationalisation and trans-local development", Entrepreneurship and Regional Development, Vol. 20 No. 6, pp. 517-532, doi: 10.1080/ 08985620802462108.

Biggeri, M., Ferrannini, A. and Borsacchi, L. (2015), "Emersione, sviluppo ed integrazione nel territorio pratese: professionalità e strumenti di facilitazione”, Ricerca, Pacini Editore, Pisa, pp. 1-207 (in Italian and in Chinese), ISBN 978-88-6315-816-8.

Canello, J. (2016), "Migrant entrepreneurs and local networks in industrial districts", Research Policy, Vol. 45 No. 10, pp. 1953-1964, doi: 10.1016/j.respol.2016.05.006.

Caroleo, F.E., Giannelli, G.C. and Pastore, F. (2010), "Vulnerability and discrimination among women, children and ethnic minorities”, International Journal of Manpower, Vol. 31 No. 2, pp. 101-108, doi: $10.1108 / 01437721011042223$.

Ceccagno, A. (2003), "New Chinese migrants in Italy", International Migration, Vol. 41, pp. 187-213.

Ceccagno, A., Rastrelli, R. and Salvati, A. (2008), Ombre Cinesi?: Dinamiche Migratorie Della Diaspora Cinese in Italia, Carocci, Roma.

Crossley, N., Bellotti, E., Edwards, G., Everett, M.G., Koskinen, J. and Tranmer, M. (2015), Social Network Analysis for Ego-Nets: Social Network Analysis for Actor-Centred Networks, Sage, London.

Deakins, D., Ishaq, M., Smallbone, D., Whittam, G. and Wyper, J. (2007), "Ethnic minority businesses in Scotland and the role of social capital", International Small Business Journal, Vol. 25 No. 3, pp. 307-326, doi: 10.1177/0266242607076530.

Dei Ottati, G. (2017), "Marshallian Industrial Districts in Italy: the end of a model or adaptation to the global economy?”, Cambridge Journal of Economics, Vol. 42 No. 2, pp. 259-284, doi: 10.1093/cje/ bex066.

Epstein, G.S. and Heizler, O. (2016), "The formation of networks in the diaspora”, International Journal of Manpower, Vol. 37 No. 7, pp. 1136-1153, doi: 10.1108/IJM-08-2015-0115.

Gereffi, G. and Lee, J. (2016), "Economic and social upgrading in global value chains and industrial clusters: why governance matters”, Journal of Business Ethics, Vol. 133 No. 1, pp. 25-38.

Gordon, I.R. and McCann, P. (2000), "Industrial clusters: complexes, agglomeration and/or social networks?”, Urban Studies, Vol. 37 No. 3, pp. 513-532, doi: 10.1080/0042098002096.

Jones, T., Ram, M. and Edwards, P. (2006), "Ethnic minority business and the employment of illegal immigrants", Entrepreneurship and Regional Development, Vol. 18 No. 2, pp. 133-150, doi: 10. 1080/08985620500531865. 
Jones, T., Ram, M., Edwards, P., Kiselinchev, A. and Muchenje, L. (2014), "Mixed embeddedness and new migrant enterprise in the UK", Entrepreneurship and Regional Development, Vol. 26 Nos 56, pp. 500-520, doi: 10.1080/08985626.2014.950697.

Kloosterman, R.C. (2010), "Matching opportunities with resources: a framework for analysing (migrant) entrepreneurship from a mixed embeddedness perspective", Entrepreneurship and Regional Development, Vol. 22 No. 1, pp. 25-45, doi: 10.1080/08985626.2014.950697.

Lee, K.M., Kim, J.Y., Lee, S. and Goh, K.I. (2014), "Multiplex networks”, Networks of Networks: the Last Frontier of Complexity, Springer, Cham, pp. 53-72.

Lombardi, S., Lorenzini, F., Verrecchia, F. and Sforzi, F. (2015), "Chinese micro-entrepreneurship in Italy: a place-based explanatory analysis", in Baldassar, L., Johanson, G., McAuliffe, N. and Bressan, M. (Eds), Chinese Migration to Europe, Palgrave Macmillan, London, pp. 287-309, doi: 10.1057/9781137400246_16.

Mehrotra, S. and Biggeri, M. (2010), "Children in home worker households in Pakistan and Indonesia”, International Journal of Manpower, Vol. 31 No. 2, pp. 208-231, doi: 10.1108/ 01437721011042278.

Ojo, S., Nwankwo, S. and Gbadamosi, A. (2013), "Ethnic entrepreneurship: the myths of informal and illegal enterprises in the UK", Entrepreneurship and Regional Development, Vol. 25 Nos 7-8, pp. 587-611, doi: 10.1080/08985626.2013.814717.

Park, S.H. and Luo, Y. (2001), "Guanxi and organizational dynamics: organizational networking in Chinese firms", Strategic Management Journal, Vol. 22 No. 5, pp. 455-477, doi: 10.1002/smj.167.

Pieke, F.N. and Mallee, H. (1999), Internal and International Migration: Chinese Perspectives, Chinese Worlds Series, Curzon Press, Richmond, Surrey.

Portes, A. and Martinez, B.P. (2020), "They are not all the same: immigrant enterprises, transnationalism, and development", Journal of Ethnic and Migration Studies, Vol. 46 No. 10, pp. 1991-2007, doi: 10.1080/1369183X.2018.1559995.

Portes, A. (1995), The Economic Sociology of Immigration, Russell Sage Foundation, New York.

Rahman, M.Z., Ullah, F. and Thompson, P. (2018), "Challenges and issues facing ethnic minority small business owners: the Scottish experience", The International Journal of Entrepreneurship and Innovation, Vol. 19 No. 3, pp. 177-193, doi: 10.1177/1465750317753932.

Randelli, F. and Lombardi, M. (2014), "The role of leading firms in the evolution of SME clusters: evidence from the Leather Products Cluster in Florence", European Planning Studies, Vol. 20 No. 12, pp. 1961-1974, doi: 10.1080/09654313.2013.773963.

Simpson, W. (2001), “QAP: the quadratic assignment procedure”, North American STATA Users' Group Meeting, pp. 12-13.

Tassinari, A. (1994), "L’immigrazione cinese in Toscana", in Campani, G., Carchedi, F. and Tassinari, A. (Eds), L'immigrazione Silenziosa. Le Comunità Cinesi in Italia, Edizioni della Fondazione Giovanni Agnelli, Torino, pp. 105-125.

Walcott, S. (2007), "Wenzhou and the third Italy: entrepreneurial model regions", Journal of AsiaPacific Business, Vol. 8 No. 3, pp. 23-35, doi: 10.1300/J098v08n03_03.

Wang, C.L. and Altinay, L. (2012), "Social embeddedness, entrepreneurial orientation and firm growth in ethnic minority small businesses in the UK", International Small Business Journal, Vol. 30 No. 1, pp. 3-23, doi: 10.1177/0266242610366060.

Yang, X., Ho, E.Y.-H. and Chang, A. (2012), "Integrating the resource-based view and transaction cost economics in immigrant business performance", Asia Pacific Journal of Management, Vol. 29 No. 3, pp. 753-772, doi: 10.1007/s10490-010-9236-2.

You, T. and Zhou, M. (2019), "Simultaneous embeddedness in immigrant entrepreneurship: global forces behind Chinese-owned nail salons in New York city", American Behavioral Scientist, Vol. 63 No. 2, pp. 166-185, doi: 10.1177/0002764218793684. 
Zolin, R., Chang, A., Yang, X. and Ho, E.Y.H. (2016), "Social capital or ethnic enclave location? A multilevel explanation of immigrant business growth", Thunderbird International Business Review, Vol. 58 No. 5, pp. 453-463, doi: 10.1002/tie.21754.

About the authors

Mario Biggeri is an Associate Professor of Applied Economics at the Department of Economics and Management, University of Florence. His research interests include local development, industrial

districts, industrial clusters of micro, small and medium enterprises, informal activities, entrepreneurial behaviour, sustainable human development, international cooperation, social innovation and impact evaluation. He is the co-author and/or co-editor of 20 books and has published extensively in a broad range of international journals. He is a scientific director of ARCO and of the Yunus Social Business Centre of the University of Florence. Mario Biggeri is the corresponding author and can be contacted at: mario.biggeri@unifi.it

Lisa Braito is a Research Fellow in Data Management and Data Science Tools for Economics and Development at the Department of Statistics, Computer Science, Applications “G. Parenti”, University of Florence. Her research interests include local development, informal activities, industrial clusters of micro, small and medium enterprises, development economics and quantitative analysis of development issues.

Annalisa Caloffi is an Associate Professor of Applied Economics at the University of Florence. Her main research interests include industrial districts and clusters, industrial and innovation policies, innovation networks and research and development (R\&D) consortia. She has been involved in a number of international research projects on clusters and innovation policies, including European Union (EU)-funded research framework projects, as well as in several projects funded by national and regional agencies. Her works have been presented at several conferences worldwide and published in peerreviewed journals, books and other national and international outlets.

Huanhuai Zhou is an Associate Professor of Zhijiang College at the Zhejiang University of Technology (formerly Associate Professor at Wenzhou University). She was a visiting scholar of the University of Florence between 2011 and 2012. Her research focus is on the entrepreneurship of migrants, especially Chinese migrants overseas. In China, she has carried out several projects on Chinese migrants overseas, which were funded by the Chinese government, and she has published several relevant articles.

For instructions on how to order reprints of this article, please visit our website:

www.emeraldgrouppublishing.com/licensing/reprints.htm

Or contact us for further details: permissions@emeraldinsight.com 